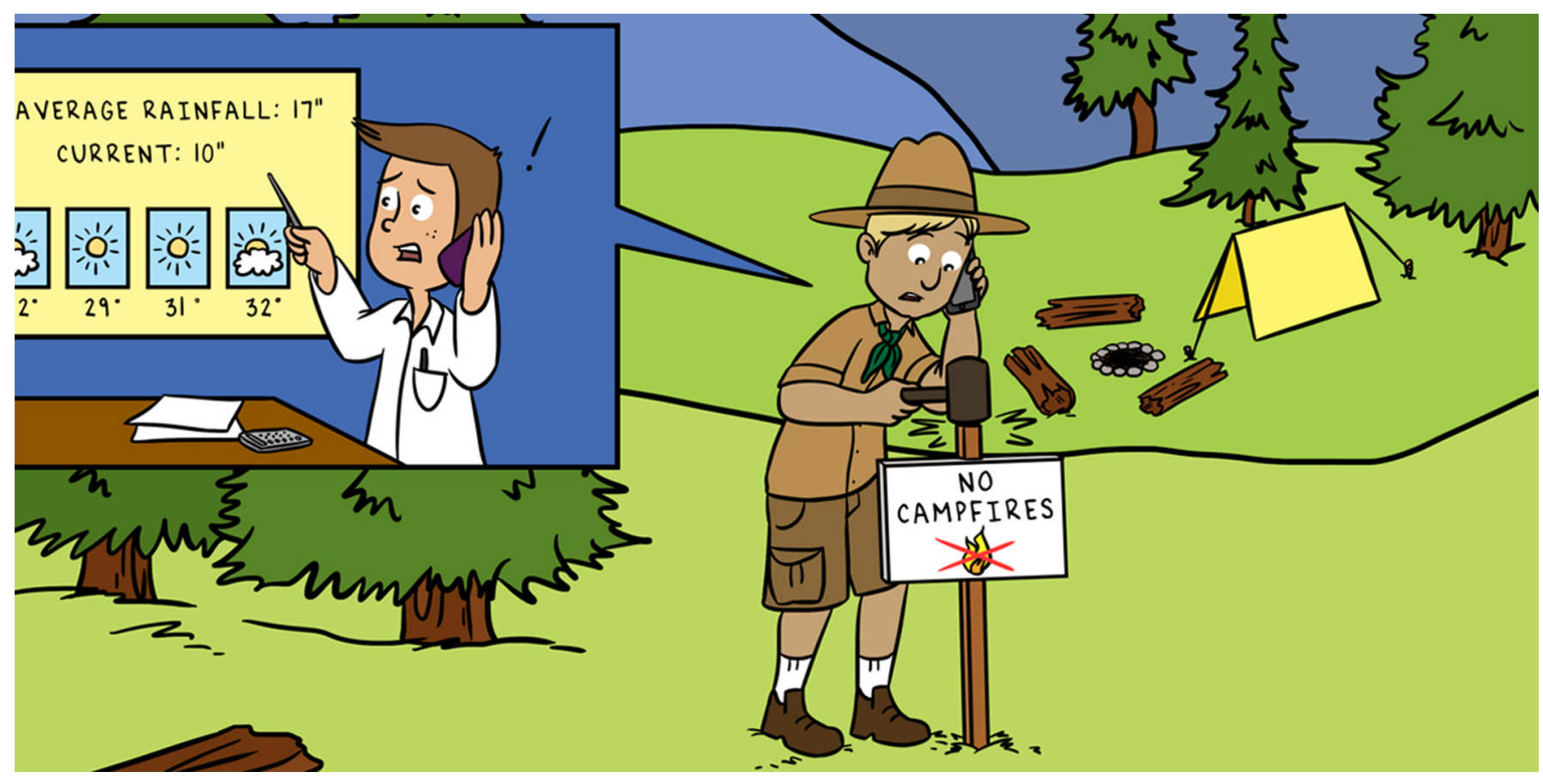

\title{
WHEN NATURE GETS THIRSTY
}

\section{Rebecca H. Weissinger ${ }^{1 *}$, David Thoma ${ }^{2}$ and Alice Wondrak Biel ${ }^{1}$}

${ }^{1}$ Northern Colorado Plateau Network, National Park Service, Moab, UT, United States

${ }^{2}$ Northern Colorado Plateau Network and Greater Yellowstone Network, National Park Service, Bozeman, MT, United States

YOUNG REVIEWERS:

ETHAN

AGE: 8

KING'S

SCHOOL,

CANTERBURY

AGES: $14-15$
Water is the fountain of life. Without water, nothing grows, including us! But not everything in nature can have all the water it needs, all the time. If plants and animals get too thirsty, they get stressed. When nature dries out, dangerous conditions like droughts and wildfires can happen. It is important for national park managers to understand where and when nature is thirsty. As scientists, we track how much water falls as rain and snow. Then we subtract how much water leaves through rivers, groundwater, and evaporation. The leftover water can be used by plants and animals. We compare how much water plants want to how much water is available, so we can know how thirsty plants are. The hotter it is, the faster water disappears. By knowing when and where nature is thirsty, park managers can take actions to help protect parks.

\section{HOW DO WE KNOW WHEN NATURE IS THIRSTY?}

How do you feel when you do not drink enough water? Your mouth gets sticky, you feel hot, and then there is that unique feeling of drying 


\section{WATER BALANCE}

The idea that water flowing into a system, like rain and snow, equals the water stored in a system plus the water flowing out of a system.

\section{EVAPORATION}

The process of water turning from liquid to gas. out. Thirst, like hunger, is a need that must be satisfied. Every plant and animal can get thirsty, no matter where they are, how big, how small, or how old. You can tell if a plant in your house is thirsty by its drooping or wilted leaves. In national parks, how can park managers tell if a forest or grassland or desert is thirsty? When does a stream or wetland become thirsty?

\section{MANY FORMS OF WATER, IN BALANCE}

Before we can understand thirst in nature, we must think about water and where it exists. Picture yourself on a hike through your favorite national park. You follow the trail around a corner and spot a beautiful watery scene. What do you see? A mountain lake? Waves on the ocean? Nice! Now put on your detective's cap and look again. Can you find more water? We will give you a hint: water is everywhere, hiding in plain sight! Water can be frozen in snow or ice. There is water running up the trunk of the tree beside you, as sap, and pulsing in the blood of a squirrel in the tree's branches. There is invisible water in the air around you. There is even water in the soil under your feet. With water in so many forms and places, how can a scientist possibly keep track of it all? We use a concept called water balance to help us out. Water balance means that the water that goes into a system is equal to the water coming out of that system. It is balanced, like a math equation!

Let us start with a system you know well: your own body. The water that goes into your body is the water you drink. Some water is stored in your cells for your body to use. You can probably think of one way that water leaves your body-as pee! Other water leaves your body when you breathe and when you sweat. If you could measure it all, you would know how much water your body uses to keep you alive and healthy. But some of that water is hard to measure, right? How do you measure the invisible water in your breath, or the sweat that keeps you cool via evaporation?

That is where a little bit of math comes in handy. If you take the inputs that are easy to measure (the amount of water you drink) and subtract the outputs that are easy to measure (the volume of your pee), there is still some water left. The leftover part is everything else: storage, sweat, and breath. So, the water you drink equals the water leaving your body, but there is some water that stays inside you to keep you alive. All of the water moving into, through, and out of your body is your personal water balance.

\section{WHAT ABOUT WATER IN NATURE?}

Water in nature works just like it does in your body. Water comes into a park as rain or snow. See if you can follow the paths water might take in a park like Yellowstone, in Figure 1. Some water fills rivers, streams, 
Figure 1

Nature's water balance has water in different "pools," like rivers, snow, soil, and air, in this example from Yellowstone National Park. Plants and animals use the different pools to survive and thrive [Conceptual diagrams by the Northern Colorado Plateau Network. Graphic elements courtesy of the Integration and Application Network, University of Maryland Center for

Environmental Science (ian.umces.edu/ symbols/)].

\section{TRANSPIRATION}

The process of water moving through a plant and out its leaves.

\section{EVAPO-}

\section{TRANSPIRATION}

The sum of water moving into the air through evaporation and transpiration.

\section{ADAPTED}

Having qualities that make it easier to live and survive in a particular place.

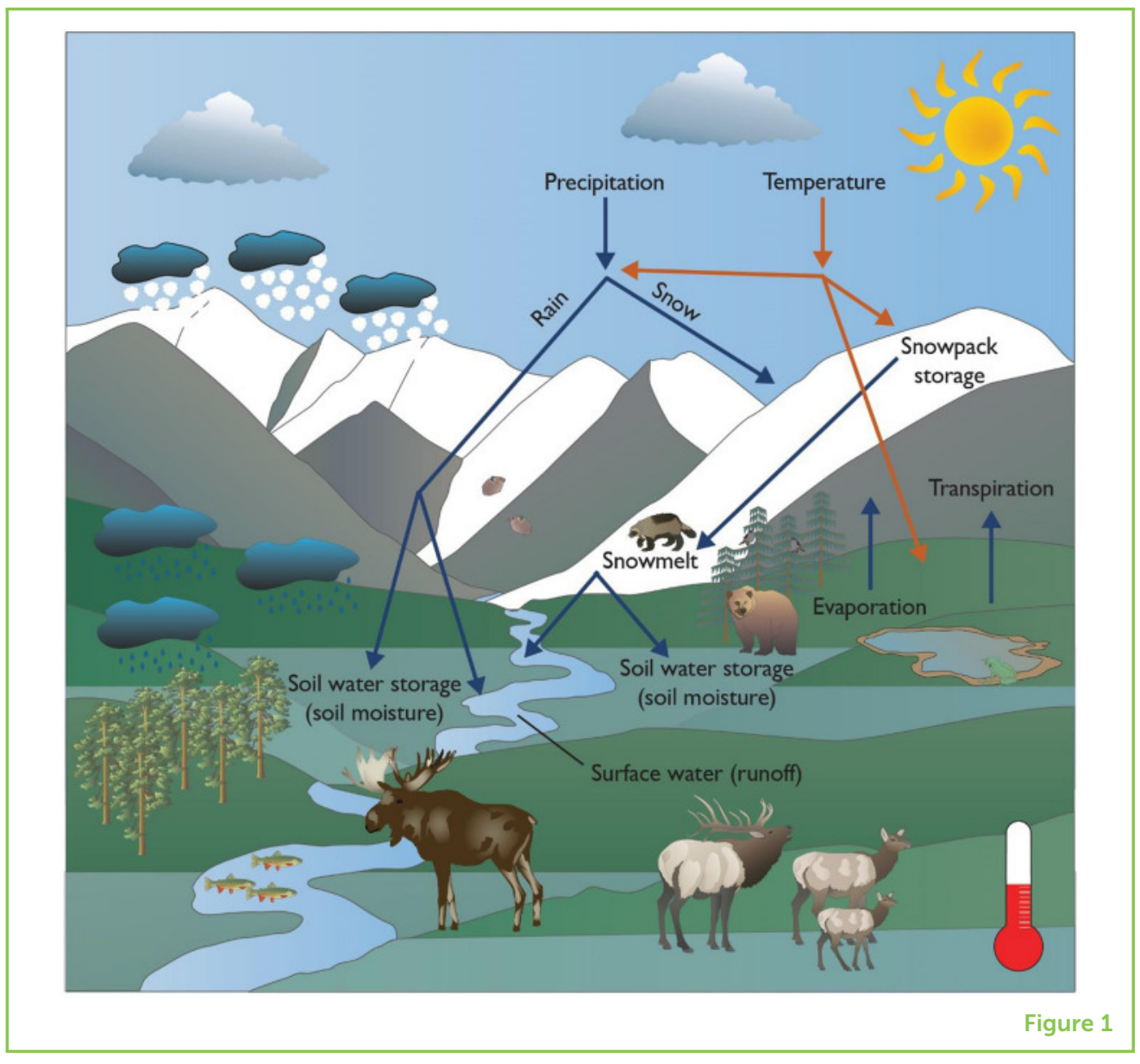

and wetlands where wildlife can take a cool drink. Other water is stored in the soil where it can be used by plants. This hidden water is like the water in your cells that keeps you alive. Like your sweat, some water evaporates from the soil and through plant leaves as they make food. Water evaporating through plant leaves is called transpiration, and it is actually the dry air pulling water through the plants, like you do when drinking from a straw. Scientists smash two words into one, to describe the process by which nature's water goes back into the air via evaporation and transpiration: evapotranspiration. Once water is in the air, it is no longer available for plants and animals to use.

To understand thirst in nature, scientists need to know how much water is in different pools (streams, wetlands, soil, and plants) and where it goes as it leaves a park. Scientists study plants and animals over time, checking their conditions in dry years and wet years. What they find again and again is that plants and animals survive in places that have the right kind of water (frozen, liquid, or gas) in the right amounts and at the right times to meet their needs. A frog and a cactus can both live in the desert if they have the right pools of water at the right times (Figure 2). We say those plants and animals are adapted to their environments. But that does not mean conditions are perfect all the time. Some years have more rain and snow than other years. It 
Figure 2

A cactus and a treefrog can both live in the desert because they use different pools of water to survive. The cactus uses water stored in the soil and in its stem, while the frog is never far from a stream or wetland (Photos by R.

Weissinger and $M$. Weissinger near Moab, Utah, USA).

\section{DROUGHT}

The duration and amount of water shortage.

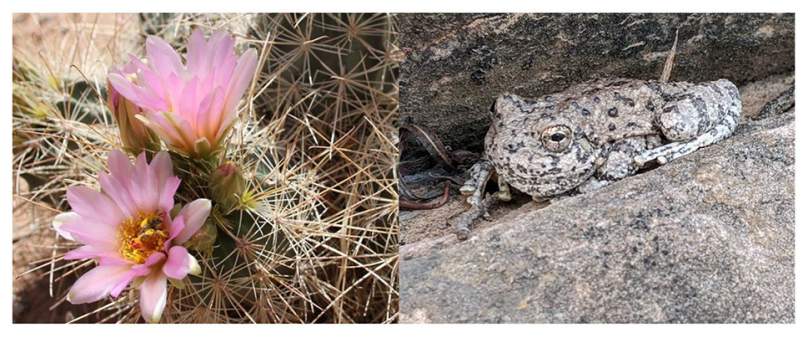

Figure 2

makes sense that nature gets thirsty when there is less rain and snow than usual, because then there is less water to go around. But another important factor helps determine thirst: heat!

\section{WHAT HAPPENS WHEN THE TEMPERATURE GOES UP?}

How much water do you drink in a day? Is the amount different if you are running around outside than if you are reading a book indoors? When you exercise, you breathe hard and sweat, losing water. This water loss can really add up! To meet your body's needs during a summer bike ride, you need to take a drink to fill up again. Just like you, plants and animals have water needs that can change. When it is hot, sunny, and dry, plants and animals run out of water faster because evapotranspiration is faster.

Remember water balance: water coming in equals water going out. If more water enters the air through evapotranspiration, then less water is available in streams, rivers, and wetlands. The soil starts to dry out, too. It becomes harder for plants and animals to get the water they need. But unlike you, a plant can not grab a glass of water, and even most animals can not move far to find water. Unless it rains or snows, nature's pools (streams, wetlands, rivers, lakes, soil moisture, water in plants and animals) get emptier and emptier. Heat is an important part of the water-balance math because it determines how quickly water moves from pools that plants and animals can use into the air, where it is inaccessible.

\section{WHAT HAPPENS WHEN PLANTS AND ANIMALS GET THIRSTY?}

When plants and animals can not have all the water they need, they get thirsty. In nature, this thirst is called drought. Every plant and animal can experience drought. Using water balance, we have found that on hot days, desert springs in Arches National Park have less water for wildlife to drink [1]. Warm winters bring less snow, changing where salamanders at Yellowstone National Park can live [2]. Dry conditions also make it harder for plants to grow and easier for forests to catch 


\section{Figure 3}

Scientists predict many changes will occur at Yellowstone National Park as temperatures go up. How many can you find, compared to Figure 1? Some of these changes are likely to happen in the future, such as changes in where wolverines and moose can live. Some have already started, like large wildfires and drying wetlands [Conceptual diagrams by the Northern Colorado Plateau Network. Graphic elements courtesy of the Integration and Application Network, University of Maryland Center for Environmental Science (ian.umces.edu/ symbols/)].

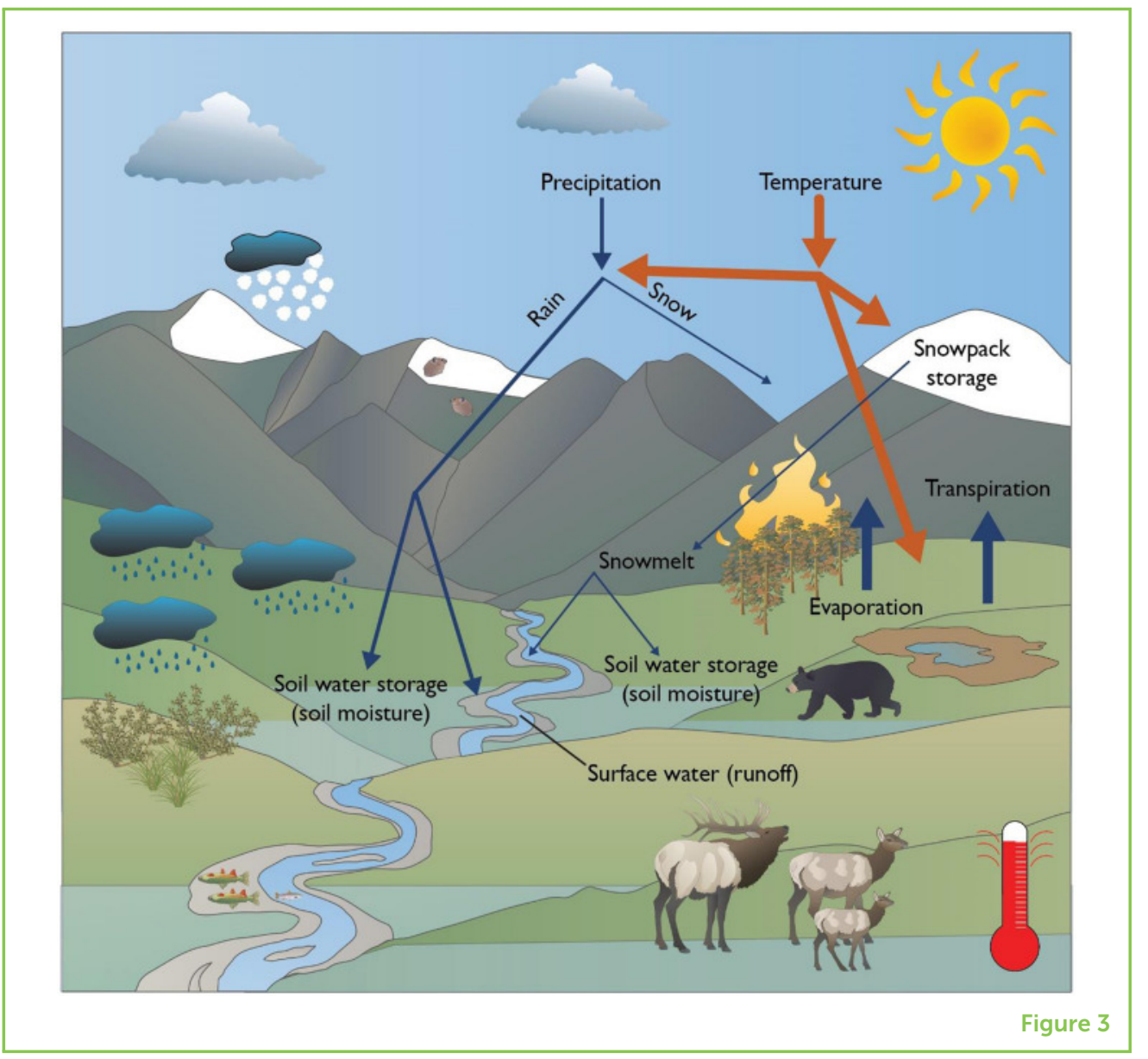

on fire and keep burning $[3,4]$. How many differences can you spot when we add heat to Yellowstone in Figure 3? Plant types change and some animals, like pikas and wolverines, move to new places [5]. A changing water balance can change individual habitats or even entire landscapes.

\section{HOW CAN WE HELP NATURE HANDLE THE HEAT?}

We know that temperatures around the world are going up. As the world gets hotter, many places we care about will experience more drought, even if the same amount of rain and snow falls. Understanding water balance can help park managers prepare for this future by helping them to know which plants and animals might have trouble, which ones might be just fine, and which places will allow plants and animals to thrive.

Park managers can not just add water to prevent drought. Parks are way too big for that. Instead, they can help plants and animals in various ways. By calculating nature's water balance, park managers know when campfires could become forest fires. They can tell when streams need more water and when fish must work harder to survive. In those cases, they might post signs that say, "No Campfires 
Allowed," or "No Fishing." When conditions improve, they take down those signs.

Being prepared for changes can help minimize the effects of drought and heat. Park managers can prepare for a warmer future by planting pine trees on cooler slopes at Yellowstone. They can choose grasses wildlife like to eat that are adapted to drought in the desert. They can use controlled fires to clear undergrowth and protect giant sequoia groves from severe wildfires. They can predict which ponds will persist for frogs and make sure to remove non-native fish that eat frogs from those ponds, to help keep the frogs safe. Park managers can even plan for drinking water sources that may go dry, so future visitors have enough to drink! By understanding how heat and water interact in nature's water balance, park managers are preparing for hotter and drier days in the future. But there is much we still need to learn. Can you help scientists find solutions for nature?

\section{REFERENCES}

1. Weissinger, R., Philippi, T., and Thoma, D. 2016. Linking climate to changing discharge at springs in Arches National Park, Utah, USA. Ecosphere 7:e01491. doi: $10.1002 /$ ecs2.1491

2. Ray, A. M., Sepulveda, A. J., Irvine, K. M., Wilmoth, S. K. C., Thoma, D. P., Patla, D. A., 2019. Wetland drying linked to variations in snowmelt runoff across Grand Teton and Yellowstone national parks. Sci. Total Environ. 666:1188-97. doi: 10.1016/j.scitotenv.2019.02.296

3. Thoma, D. P., Tercek, M. T., Schweiger, E. W., Munson, S. M., Gross, J. E., and Olliff, S. T., 2020. Water balance as an indicator of natural resource condition: case studies from Great Sand Dunes National Park and Preserve. Glob. Ecol. Conserv. 24:e01300. doi: 10.1016/j.gecco.2020.e01300

4. Allen, C. D., Breshears, D. D., and McDowell, N. G. 2015. ESA Centennial Paper on underestimation of global vulnerability to tree mortality and forest die-off from hotter drought in the Anthropocene. Ecosphere 6:1-55. doi: 10.1890/ES15-00203.1

5. Ashton, I. 2010. Observed and Projected Ecological Response to Climate Change in the Rocky Mountains and Upper Columbia Basin, Natural Resource Report NPS/ROMN/NRR-2010/220. Fort Collins, CO.

SUBMITTED: 24 September 2020; ACCEPTED: 02 July 2021; PUBLISHED ONLINE: 29 July 2021.

EDITED BY: Anna Regoutz, University College London, United Kingdom

CITATION: Weissinger RH, Thoma D and Biel AW (2021) When Nature Gets Thirsty. Front. Young Minds 9:610018. doi: 10.3389/frym.2021.610018

CONFLICT OF INTEREST: The authors declare that the research was conducted in the absence of any commercial or financial relationships that could be construed as a potential conflict of interest. 


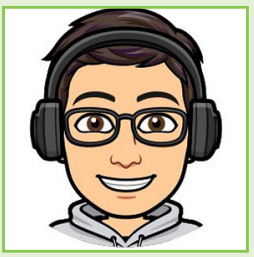

\section{YOUNG REVIEWERS}

\section{ETHAN, AGE: 8}

Ethan is an 8-years old boy that is currently in the third grade. He enjoys reading, writing, and studying math and history. During his free time, he plays basketball, tennis, and various other sports with his younger brother. He also loves exploring and learning about the nature. He lives in Virginia with his younger brother and parents. One day, he hopes to get a pet.

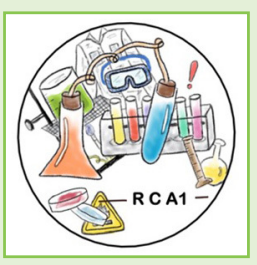

\section{KING'S SCHOOL, CANTERBURY, AGES: 14-15}

We are an energetic year 10 class who are curious about the latest science. We are glad that scientists are doing their best to continue their research in these difficult times! It makes us happy that we can support them through this review.

\section{AUTHORS}
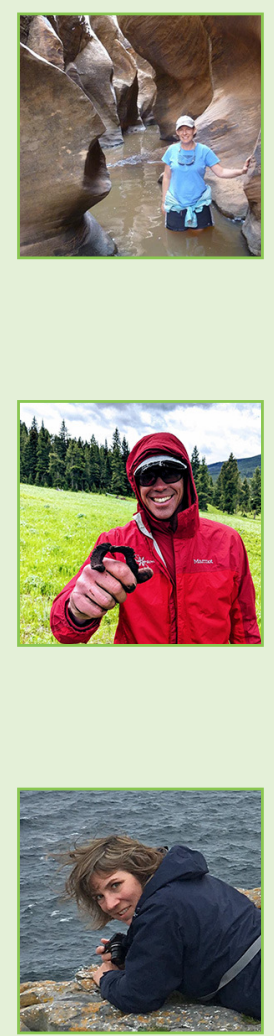

\section{REBECCA H. WEISSINGER}

Rebecca H. Weissinger studies water in national parks in Utah and Colorado. She has two kids and likes to go hiking, boating, and camping with her family. The most fun part of her job is hiking to springs in the desert. The most challenging part of her job is trying to understand how water moves underground where you can not see it. The best days of her job are when she uses science to help a park protect its water for the future. *rebecca_weissingeranps.gov

\section{DAVID THOMA}

David Thoma studies water in all its forms and how it affects nature in national parks. Here he is testing the soil to see how much water it can hold. He uses measurements made on the ground along with measurements made from satellites to understand nature's response to water abundance and shortage. He loves studying water balance in nature! This can help managers understand how nature may respond to climate change and what they can do to help.

\section{ALICE WONDRAK BIEL}

Alice Wondrak Biel helps scientists express their thoughts through writing and images. Most of her job is done in front of a computer, working with words and pictures to make sure everyone can benefit from the stories scientists have to tell. But one of the best parts of her job is when she gets to go out and see things through her own lens! 